\title{
Expression of voltage-gated sodium channel $\alpha$ subunit in human ovarian cancer
}

\author{
RUI GAO $^{1}$, YI SHEN ${ }^{1}$, JING CAI $^{1}$, MING LEI $^{2}$ and ZEHUA WANG ${ }^{1}$ \\ ${ }^{1}$ Department of Obstetrics and Gynecology, ${ }^{2}$ Centre for Ion Channel Research, Department of Cardiovascular Diseases, \\ Union Hospital, Tongji Medical College, Huazhong University of Science and Technology, Wuhan 430022, P.R. China
}

Received November 26, 2009; Accepted January 11, 2010

DOI: $10.3892 /$ or_00000763

\begin{abstract}
Voltage-gated sodium channels (VGSC) play important roles in the development and progression of many cancers. We report the possible roles of VGSC in human ovarian cancer. Relative mRNA expression levels of Nav1.1, Nav1.3, Nav1.4 and Nav1.5, analyzed by RT-PCR, were significantly higher in ovarian cancers cells compared with normal ovarian tissues; relative mRNA expression levels of Nav1.2, Nav1.4, Nav1.5 and Nav1.7 were significantly increased in highly metastatic ovarian cancer cells (Caov-3 and SKOV-3) compared with low-metastatic ovarian cancer cells (Anglne). Treatment of $30 \mu \mathrm{M}$ tetrodotoxin reduced by $50-60 \%$ migration and invasion of Caov-3 and SKOV-3 without affecting proliferation. Real-time PCR, Western blot analysis and immunohistochemistry assays revealed that functional expression levels of Nav1.5 might be correlated with the grade and metastasis of ovarian cancer. Our findings suggested that abnormal expression of Nav1.5 could be an integral component of the metastatic process in human ovarian cancer and might serve as a therapeutic target in ovarian cancer treatment.
\end{abstract}

\section{Introduction}

Ovarian cancer is the most fatal cancer in women in the world. The overwhelming majority of patients are found at advanced disease stage because of no obvious symptoms. Therefore, it is necessary to find effective diagnosis and therapy methods (1).

Ion channels are functionally expressed in almost all tissues and cell types as the main signaling molecules (2). With the development of patch clamp technique and molecular biology, recent studies have revealed that ion channels were

Correspondence to: Dr Zehua Wang, Department of Obstetrics and Gynecology, Union Hospital, Tongji Medical College, Huazhong University of Science and Technology, Wuhan 430022, P.R. China E-mail: zehuawang@163.net

Key words: voltage-gated sodium channel, Nav1.5, splice variant, ovarian cancer, migration, invasion associated with different aspects of carcinogenic process by involving in cell proliferation, multidrug resistance, migration and invasion $(3,4)$. The functional expression levels of potassium, calcium and chloride channels had been widely investigated over the past few decades, but little is known about the sodium channels in ovarian cancer $(5,6)$.

Voltage-gated sodium channel (VGSC) mediates an inward sodium current during the initial phase of potential action in excitable cells, composed of principal $\alpha$ subunit (VGSC $\alpha$ ) and auxiliary $\beta$ subunits (VGSC $\beta$ ) (7). A window of voltage has been found at cancer cellular normal membrane potential, where there is a continuous entry of sodium because of the partial opening of VGSC $\alpha$, the entry sodium might be responsible for the disrupting intracellular ion homeostasis $(6,8)$. Therefore, it is important to investigate the roles of VGSC $\alpha$ in carcinogenic process. The functional subunits of VGSC $\alpha$ are the Nav1 family (Nav1.11.9), each member of the Nav1 family consists of 4 homologous domains (D1-D4) and every domain has 6 transmembrane segments (S1-S6) (9). Tetrodotoxin (TTX) is the specific blocker of VGSC, according to the sensitivity to TTX, VGSC is described TTX-sensitive (TTX-S; Nav1.1-1.4, Nav1.6-1.7) and TTX-resistant (TTX-R; Nav1.5, Nav1.8-1.9) (10). Among the family, Nav1.5 and Nav1.7 have been found to potentiate metastasis of many cancers (11-13).

The aim of this study was to investigate the functional expression of VGSC $\alpha$ in human ovarian cancer; the possible correlation between VGSC $\alpha$ activity and cellular behaviour integral to metastasis; as well as whether inhibition of VGSC $\alpha$ can serve a novel treatment of ovarian cancer.

\section{Materials and methods}

Cell culture. Human ovarian cancer cell lines Anglne, Caov-3 and SKOV-3 were obtained from the China Type Culture Collection (CTCC). Anglne cells are characterized by low rate of metastasis to non-specific sites; Caov-3 and SKOV-3 cells display a high rate of metastasis (14). Cells were cultured at $37^{\circ} \mathrm{C}$ with $5 \% \mathrm{CO}_{2}, 95 \% \mathrm{O}_{2}$ in DMEM with $10 \%$ fetal bovine serum, $50 \mathrm{IU} / \mathrm{ml}$ penicillin, $50 \mathrm{ng} / 1$ streptomycin and $0.3 \mathrm{ng} / \mathrm{l}$ glutamine.

Patient specimen. Four normal ovary (N1-N4) and 53 ovarian tumor specimens were included in the study (mean patient age: 47 years, range: $24-72$ years), followed up at the 
Table I. Primers used for determination of VGSC $\alpha$ mRNA expressed in human ovarian cancer.

\begin{tabular}{|c|c|c|}
\hline Gene product & Forward primer/Reverse primer $\left(5^{\prime}>3^{\prime}\right)$ & Predicted size (bp) \\
\hline Nav1.1 & $\begin{array}{l}\text { ACCCGACTGTGACCCTAATA } \\
\text { GAATCGCTCTTCCATCTGTA }\end{array}$ & $466(5185-5646)$ \\
\hline Nav1.2 & $\begin{array}{l}\text { TCCAAGACGCAACAGTAGGGC } \\
\text { CCAGCAGATGTGAGGGTAGAA }\end{array}$ & 297 (1704-2000) \\
\hline Nav1.3 & $\begin{array}{l}\text { CCTCAGAAACCCATACCTCG } \\
\text { TCAGCCAGAAACATACCTACAA }\end{array}$ & $314(4510-4823)$ \\
\hline Nav1.4 & $\begin{array}{l}\text { CGAGTCATTCGCACCATCCTA } \\
\text { GGCAGACAAGCAGCACATTCA }\end{array}$ & $328(3175-3502)$ \\
\hline Nav1.5-1 & $\begin{array}{l}\text { ATTCTGGTTCACTCGCTCTTCA } \\
\text { CACGCACTTGTGCCTTAGGTT }\end{array}$ & $465(573-1037)$ \\
\hline Nav1.5-2 & $\begin{array}{l}\text { TCGTGAACAACAAGAGCCAGTG } \\
\text { GGTGAAGAAAGACCCAAAGATGA }\end{array}$ & $254(4324-4577)$ \\
\hline Nav1.5-3 & $\begin{array}{l}\text { TCACCCACATGTGCCCATCTACGA } \\
\text { GACAAATTGCCTAGTTTTATATTT }\end{array}$ & $211(631-841)$ \\
\hline Nav1.6 & $\begin{array}{l}\text { CGCCTTATGACCCAGGACTA } \\
\text { GTGCCTCTTCCTGTTGCTTC }\end{array}$ & 247 (1271-1517) \\
\hline Nav1.7-1 & $\begin{array}{l}\text { AAGTTTCCACCTTGGTGTCG } \\
\text { TTGGCTGATGTTACTGCTGC }\end{array}$ & $277(1584-1860)$ \\
\hline Nav1.7-2 & $\begin{array}{l}\text { ATGACCATGAATAACCCACCG } \\
\text { TCAGGTTTCCCATGAACAGC }\end{array}$ & $389(474-862)$ \\
\hline Nav1.8 & $\begin{array}{l}\text { ATCTACTCTATCTTCGGTATGTCCG } \\
\text { GAAGGAGAGAGATGTAGGTGGT }\end{array}$ & $273(4858-5130)$ \\
\hline Nav1.9 & $\begin{array}{l}\text { ACTGTGATGACTGACCCGTTTA } \\
\text { ATTTGGCTAACTTGAAGACCCTG }\end{array}$ & 334 (1714-2047) \\
\hline B-actin & $\begin{array}{l}\text { TCACCCACATGTGCCCATCTACGA } \\
\text { CAGCGGAACCGCTCATTGCCAATG }\end{array}$ & $295(549-843)$ \\
\hline
\end{tabular}

Division of Gynecologic Oncology of Union Hospital (Wuhan, China) between November 2004 and January 2008. Among 53 ovarian tumor specimens, 23 (43.4\%) were ovarian benign tumors, $30(56.6 \%)$ were ovarian epithelial cancer (11 having lymph node metastasis, LNM). Written informed consent was obtained from all patients enrolled in this study.

RNA extraction and reverse transcription polymerase chain reaction $(R T-P C R)$. Total RNA was extracted from ovarian cancer cell lines and ovarian biopsy specimens by using TRIzol (Invitrogen, USA) according to the manufacturer's instructions, $1 \mu \mathrm{g}$ total RNA was generated for the reverse transcription reaction using Rever Tra Ace kit (Toyobo, Japan). PCR analysis was performed with Taq DNA polymerase (Promega, USA). Primers were designed between at least two exons and specific for each subunits (see Table I). Primers for Nav1.5 and Nav1.7 were, respectively, designed at D1:S1-S5 (Nav1.5-1), D3:S5-S6 (Nav1.5-2), D1:S6-D2:S1 (Nav1.7-1) and D1:S2-S5 (Nav1.7-2). The reaction cycles for all genes were run with: $95^{\circ} \mathrm{C}$ for $5 \mathrm{~min}, 94^{\circ} \mathrm{C}$ for $1 \mathrm{~min}, 60^{\circ} \mathrm{C}$ for $1 \mathrm{~min}, 72^{\circ} \mathrm{C}$ for $1 \mathrm{~min}$ and $72^{\circ} \mathrm{C}$ for $7 \mathrm{~min}$. Fifty amplification cycles were necessary to achieve exponential amplification. PCR products were run on $2 \%$ agarose gels, the results of electrophoresis were analyzed by GDS 8000 Gel Imaging Assay System (Gene Company). Relative gene expression was defined as a ratio of target gene to $\beta$-actin gene. The PCR products were sequenced by Invitrogen Biotechnology Co., Ltd (Shanghai, China).

Cell proliferation assay. Proliferation was measured by CellCounting Kit (CCK)-8 (Dojindo, Japan). Cells were plated in 96-well plates at $1 \times 10^{4}$ cells per well, then incubated with different concentration TTX $(0-30 \mu \mathrm{M})$ for $24 \mathrm{~h}$. At the indicated time points, $10 \mu \mathrm{l}$ of the CCK- 8 solution was added into the triplicate wells and incubated for $1.5 \mathrm{~h}$, the absorbance at $450 \mathrm{~nm}$ was measured to calculate the numbers of vital cells in each well. Data were obtained from three separate experiments and each treatment vs. control was performed in triplicate.

In vitro migration and invasion assay. Invasion assays were performed using a Transwell chemotaxis chamber $(8 \mu \mathrm{m}$, Corning, USA). Matrigel (BD, USA) was diluted to $1 \mathrm{mg} / \mathrm{ml}$ in serum-free DMEM medium, $50 \mu 1$ Matrigel was placed into all the inserts. The inserts were incubated at $4^{\circ} \mathrm{C}$ for $2 \mathrm{~h}$ and $37^{\circ} \mathrm{C}$ for $4 \mathrm{~h}$ to allow gel polymerisation. Cells were 
A

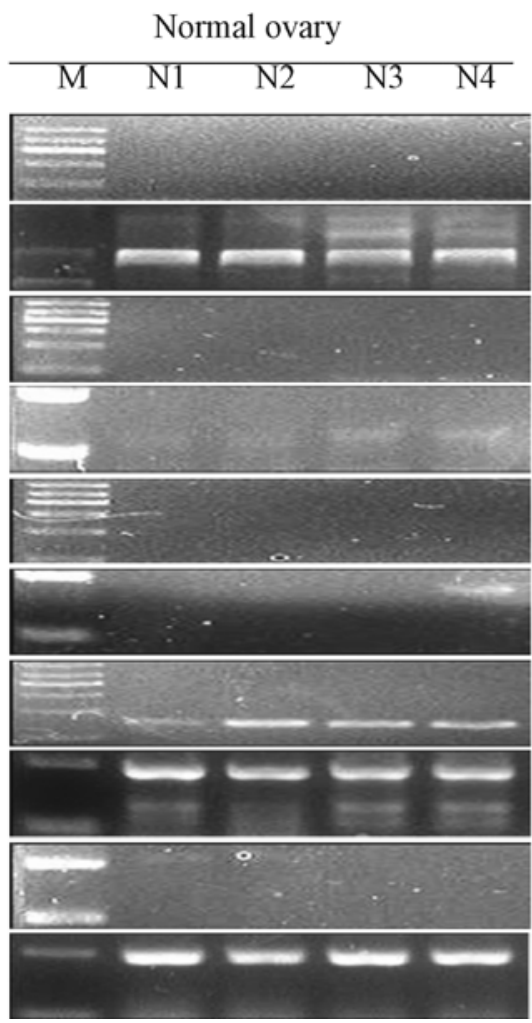

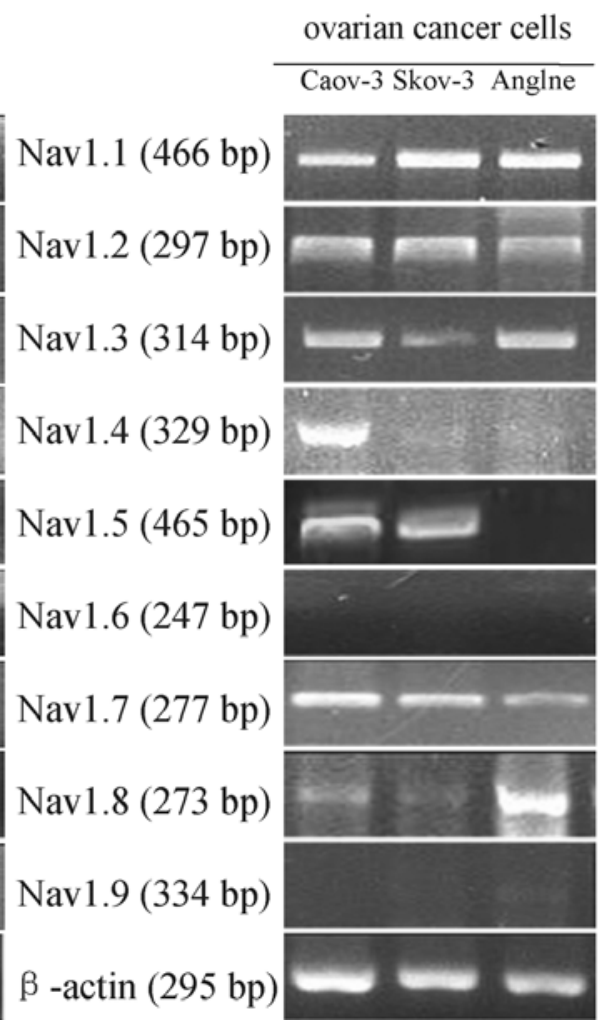

$\mathrm{B}$
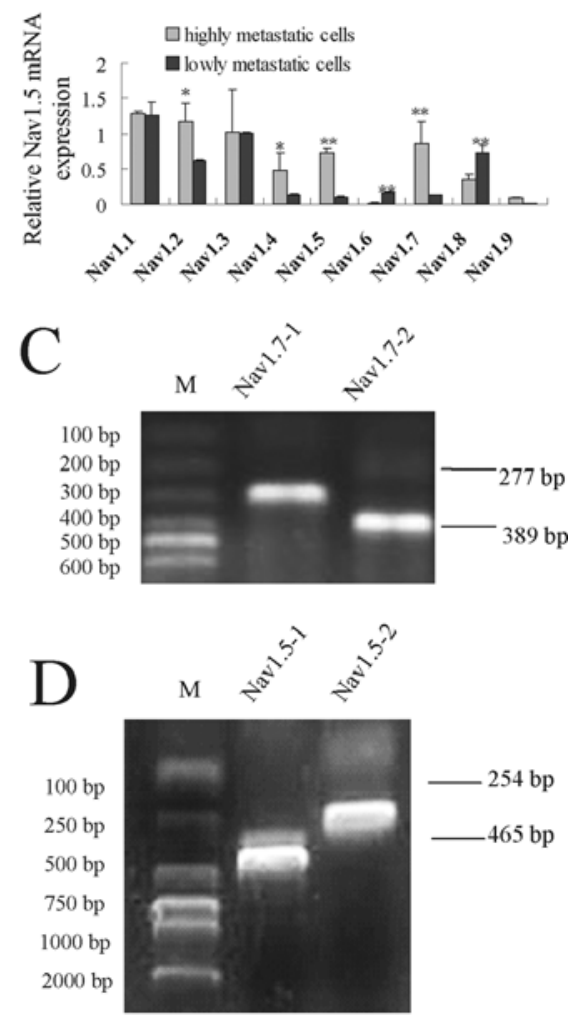

Figure 1. (A) The expression levels of Nav1 mRNA in ovarian cancer cell lines; (B) the relative expression levels of Nav1 mRNA in highly metastatic ovarian cancer cells and low-metastatic ovarian cancer cells; (C) the Nav1.5 splice forms expressed in Caov-3 cells; (D) the Nav1.7 splice forms expressed in Caov-3 cells. M, Marker; N1-N4, normal ovary tissue 1-4, expression levels were determined by densitometry scanning of the Nav1 bands and normalized to the 3 -actin bands, values are expressed as the mean \pm SME. ${ }^{*} \mathrm{P}<0.05,{ }^{* *} \mathrm{P}<0.01$ relative to 'normal ovary' or low-metastatic ovarian cancer cells.

harvested and suspended in DMEM containing 10\% FBS. The inserts were washed with the appropriate serum-free medium, then the upper inserts was seeded with $2 \times 10^{5}$ cells and lower inserts was filled with $600 \mu 1$ DMEM supplemented with $20 \%$ FBS. Cells were incubated at $37^{\circ} \mathrm{C}$ for $24 \mathrm{~h}$ and the inner side of the insert was wiped with a wet swab to remove the cells, the outer side of the insert was gently rinsed with PBS and stained with $\mathrm{H} \& \mathrm{E}$. The inserts were then viewed under microscope; the number of cells was counted at $\mathrm{x} 100$ magnification in 10 random fields. The procedure for motility assays was the same as the invasive assays except the inserts were coated with Matrigel. Migration and invasion assays were performed in triplicate in three separate experiments (control group, TTX-S group, TTX-R group). The TTX concentration of TTX-S and TTX$\mathrm{R}$ groups were, respectively, $1 \mu \mathrm{M}$ and $30 \mu \mathrm{M}$, which fully blocked the activity of TTX-S and TTX-R VGSC (13). Results obtained for migration and invasion were normalized to the control conditions.

Real-time PCR. To evaluate accurately the expression levels of Nav1.5 mRNA in ovarian tumors, real-time PCR utilizing SYBR-Green 1 (Toyobo) technology was performed. B-actin was also measured in each sample as a control gene and to normalize the respective measured Nav1.5 expression. The primer for Nav1.5-3 was designed at D1:S1-S3 of Nav1.5 (see Table I). Amplification was via an initial denaturation at $95^{\circ} \mathrm{C}$ for $3 \mathrm{~min}$ to activate the HotStar Taq, with subsequent three-step cycling of $95^{\circ} \mathrm{C} 30 \mathrm{sec}, 60^{\circ} \mathrm{C} 30 \mathrm{sec}$ and $72^{\circ} \mathrm{C} 30 \mathrm{sec}$. Triplicate reactions on each sample cDNA were carried out simultaneously for Nav1.5 and B-actin. Blank reactions without added cDNA were performed in order to control for cross contamination. The values of amplification cycle $(\mathrm{Ct})$ were analyzed by the $2^{-\Delta \Delta \mathrm{CT}}$ method to determine target expression levels (15).

Western blot analysis. Total proteins were extracted from ovarian cancer cell lines, 4 normal ovarian tissues and 11 ovarian cancer tissues with LNM. Total protein concentration was determined by the BCA assay (Pierce, USA). The protein samples were boiled for $10 \mathrm{~min}$ in $5 \mathrm{X}$ sodium dodecyl sulfate (5X SDS) sample buffer and were loaded at concentration of $100 \mu \mathrm{g} /$ well and run on a $6 \%$ sodium dodecyl sulfate polyacrylamide gel electrophoresis. Protein samples were then transferred to PVDF membranes. After saturating for $3 \mathrm{~h}$ in $5 \%$ non-fat milk TBST solution (Trisbuffered saline containing $0.5 \%$ Tween-20), the membranes were incubated overnight at $4{ }^{\circ} \mathrm{C}$ with the Nav1.5 rabbit primary antibody (1:500, Alomone labs, Israel), the polyclonal rabbit anti- $\beta$-actin antibody (1:300, Santa Cruz, USA) was used as a control for this experiment. The membranes were then incubated for $1 \mathrm{~h}$ at room temperature with a goat anti- 
rabbit secondary antibody (1:5000; Pierce). Immunoblots were visualized with the ECL immuno-detection system (Pierce). The differences between the absorbency volume of Nav1.5 and B-actin were used as the relatively absorbency of target protein expression.

Immunohistochemistry. Antigen retrieval was achieved by boiling the sections in $0.01 \mathrm{M}$ citrate buffer ( $\mathrm{pH}$ 6.0) for $10 \mathrm{~min}$ in a microwave. In order to enhance staining, sections were treated with $0.3 \%$ Triton X-100 in phosphate-buffered saline (PBS) for 10 min before the inhibition of endogenous peroxidase activity by $3 \% \mathrm{H}_{2} \mathrm{O}_{2}$ methanol application. Processed sections were incubated with anti-Nav1.5 antibody (1:100) at $4^{\circ} \mathrm{C}$ overnight, then washed and unspecific secondary antibody sites blocked by applying goat serum for $15 \mathrm{~min}$ at room temperature. Signal detection was achieved using HRP anti-rabbit goat secondary antibody. The primary antibody was omitted as negative controls in this study. For each sample, four microscopic fields in three different sections, were counted.

Statistical analysis. Statistical significance was determined by Student's t-test and one way ANOVA using SPSS12.0. A difference of $\mathrm{P}<0.05$ was considered to be statistically significant.

\section{Results}

Expression of Nav1 mRNA in ovarian cancer. As shown in Fig. 1A, mRNA expression levels of Nav1.1 to Nav1.9 were detected in ovarian cancer cells and normal ovary; relative mRNA expression levels of Nav1.2, Nav1.6, Nav1.7 and Nav1.9 did not show significant differences between ovarian cancer cells and normal ovary; amounts of mRNA expressing Nav1.1, Nav1.3, Nav1.4 and Nav1.5 were significantly higher in ovarian cancer cells than in normal ovary; the amounts of mRNA expressing Nav1.8 were obviously increased in ovarian cancer cells compared to normal ovary. Additionally, relative mRNA expression levels of Nav1.2, Nav1.4, Nav1.5 and Nav1.7 in highly metastatic cells were significantly increased compared to the low-metastatic cells; while amounts of mRNA expressing Nav1.6 and Nav1.8 were obviously decreased in highly metastatic cells compared to low- metastatic cells (Fig. 1B). Sequencing of Nav1.5 and Nav1.7 PCR products revealed that D1:S3 5' splice variants of Nav1.5 and Nav1.7 were the main forms existing in ovarian cancer cells (Fig. 1C and D).

Effect of inhibition of VGSC on ovarian cancer cell proliferation, migration and invasion. Blocking VGSC by treatment with $30 \mu \mathrm{M}$ TTX in Caov-3 and SKOV-3 decreased their migration and invasion $(62.37 \pm 4.95 \%$ and $56.56 \pm 5.51 \%)$ and $(50.44 \pm 2.78 \%$ and $58.68 \pm 1.53 \%)$, respectively, without significant alteration of cell proliferation; while a lower concentration $(1 \mu \mathrm{M})$ of TTX had no obvious effect on migration and invasion of these cells; in contrast to Caov-3 and SKOV-3 cells, Anglne cells were unable to migrate across the Transwell filters and the metastasis activity was unaffected by $1 \mu \mathrm{M}$ and $30 \mu \mathrm{M}$ TTX treatments (Fig. 2A-C).

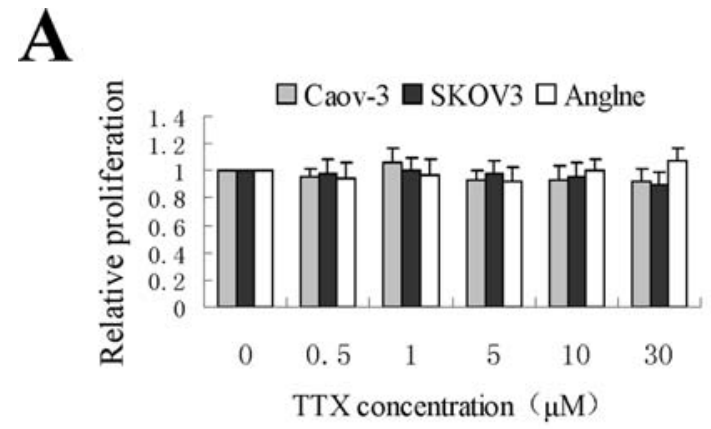

B

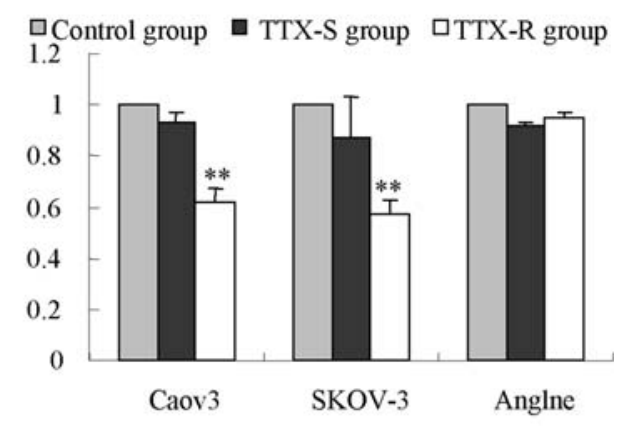

C

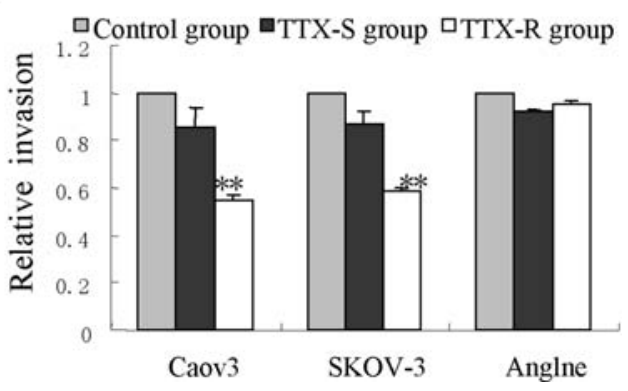

Figure 2. (A) Relative effect of 0-30 $\mu \mathrm{M}$ TTX concentration on ovarian cancer cell proliferation; (B) relative number of cells migrating through a Transwell chamber for $7 \mathrm{~h}$ treated with different concentration TTX; (C) relative effect of the TTX on cells invasion. Control group, $0 \mu \mathrm{M}$ TTX; TTX-S group, $1 \mu \mathrm{M}$ TTX; TTX-R group, $30 \mu \mathrm{M}$ TTX. Data shown here are with respect to corresponding control, untreated cells (treated as $100 \%$ ), values are expressed as the mean $\pm \mathrm{SME} .{ }^{*} \mathrm{P}<0.05,{ }^{* *} \mathrm{P}<0.01$ relative to control group.

Expression of Nav1.5 mRNA in ovarian cancer. As shown in Fig. 3A, relative mRNA expression levels of Nav1.5 were much higher in ovarian cancer compared with normal ovary and there were no significant differences between benign ovarian tumor and normal ovary. Relative mRNA expression levels of Nav1.5 in ovarian cancer with LNM were obviously increased compared to ovarian cancer without LNM (Fig. 3B). Relative mRNA expression levels of Nav1.5 in ovarian cancer tissues were significantly increased compared with ovarian cancer cells (Fig. 3C).

Expression of Nav1.5 protein in ovarian cancer. Immunohistochemistry staining revealed that Nav1.5 expression was present in ovarian cancer epithelial structures but absent from the normal ovary (Fig. 4A). Western blot assays detected that there were almost no Nav1.5 protein expression in the normal ovary, the Nav1.5 mRNA in ovarian cancer might be 

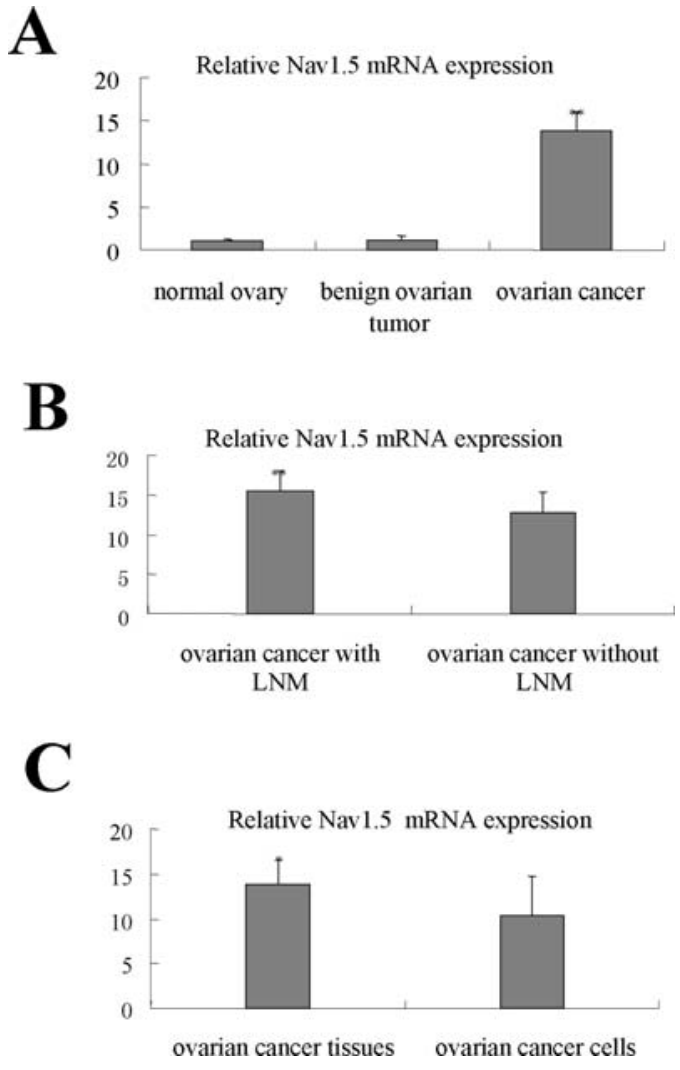

Figure 3. (A) Relative expression levels of Nav1.5 mRNA in normal ovary $(n=4)$, ovarian benign $(n=23)$, ovarian cancer $(n=30)$; $(B)$ relative expression levels of Nav1.5 mRNA in ovarian cancer tissues with LNM $(n=11)$ or without LNM $(\mathrm{n}=19)$; (C) relative expression levels of Nav1.5 mRNA in ovarian cancer tissues $(n=30)$ and ovarian cancer cells $(n=3) .{ }^{*} \mathrm{P}<0.05$ ${ }^{* *} \mathrm{P}<0.01$ relative to normal ovary, ovarian cancer tissues without LNM or ovarian cancer cells. translated into proteins of two molecular weights: the larger band of $\sim 220 \mathrm{kDa}$ corresponding to the expected normal size of the Nav1.5, the other smaller band $\sim 30 \mathrm{kDa}$ less than normal Nav1.5 (Fig. 4B).

\section{Discussion}

In the present study, we demonstrated that VGSC $\alpha$ expression levels were significantly up-regulated in human ovarian cancer; $30 \mu \mathrm{M}$ TTX markedly reduced the migration and invasion of Caov-3 and SKOV-3 cells suggesting the correlation of VGSC $\alpha$ and ovarian cancerous progression.

The 5-year survival rate of ovarian cancer is the lowest in gynecological malignancies. In order to overcome this situation, novel markers and therapeutic strategies are urgently needed. The association between VGSC $\alpha$ and the carcinogenic process of many cancers has been investigated (6). In this study, relative mRNA expression levels of Nav1.1, Nav1.3, Nav1.4 and Nav1.5 were obviously increased in ovarian cancer cells compared with normal ovarian cells; relative mRNA expression levels of Nav1.2, Nav1.4, Nav1.5 and Nav1.7 were significantly increased in highly metastatic cells compared to low-metastatic cells. However, because of Nav1.1 and Nav1.3 having similar structure and function, studies have also reported that neither Nav1.1 nor Nav1.3 produce sodium current; on the other hand, the transient expression of Nav1.4 could increase the invasive capacity of prostate cancer but relative expression levels of mRNA were very different between the cell types $(11,16-18)$.

The enhancement of VGSC activity is known to associate with cellular invasion, secretion, motility, volume and adhesion $(5,6)$. In this study, pre-treatment with $30 \mu \mathrm{M}$ TTX

\section{A}
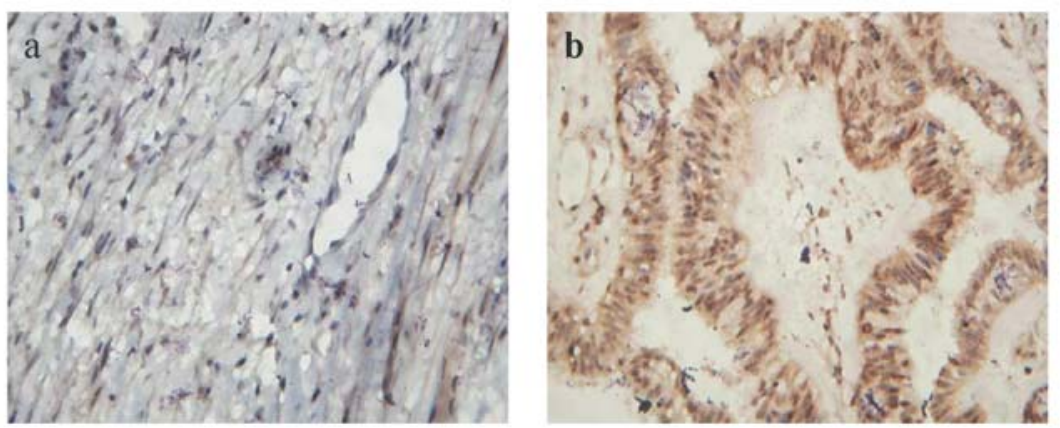

B

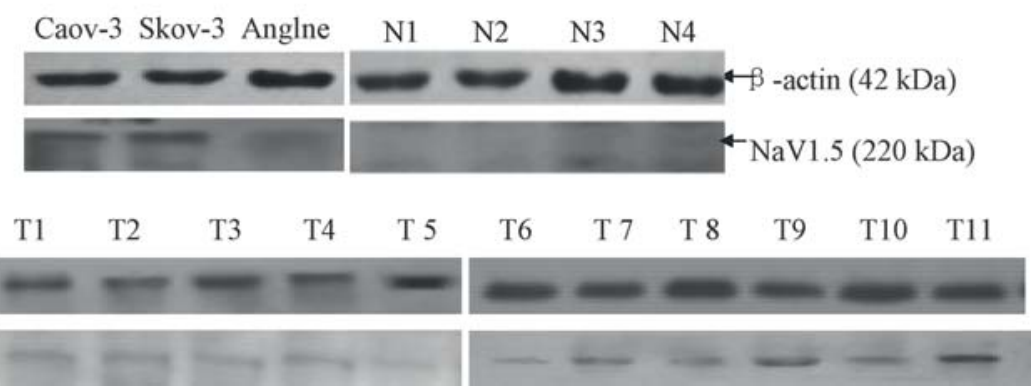

Figure 4. (A) Immunohistochemistry of Nav1.5 expression in ovary specimens. (a, normal ovary tissue; b, ovarian cancer tissue with LNM, x100); (B) the expression of Nav1.5 protein in normal ovary (N1-N4, n=4), ovarian cancer cell lines $(n=3)$ and ovarian cancer with LNM (n=11, T1-T11 denote the ovarian cancer specimens with LNM). 
reduced the migration and invasion capacity of Caov-3 and SKOV-3 cells; $1 \mu \mathrm{M}$ TTX did not reduce the migration and invasion. Therefore, the functional expression VGSC in Caov-3 and SKOV-3 cells might be the TTX-R Nav1.5 but not TTX-S Nav1.2 and Nav1.7. It was suggested that the Caov-3 and SKOV-3 cells might be more excitable than normal cells and Anglne cells (19). There are some discrepancies between our results and previous findings, reporting that incubation of human highly metastatic breast cancer cells with TTX could decrease their invasive capacity, but not invasion $(20,21)$. The reason for such discrepancy is not clear yet, it might be due to the different experiment condition, such as biochemical constitution of extracellular medium (5\% FBS or $10 \%$ FBS), pre-treatment time $(4,24$ or $48 \mathrm{~h}$ ) or cell passage $(20,22)$.

According to the differences of Nav1.5 mRNA in ovarian cancer, it was suggested that the expression levels of Nav1.5 mRNA might be correlated with the grade and metastasis of ovarian cancer. In addition, relative expression levels of Nav1.5 mRNA were also increased in ovarian cancer tissues compared with ovarian cancer cells. Identical pre-mRNA molecules are spliced in different ways, they not only create diversity in proteins in the development of normal organisms, but also cause some errors in gene translation (23). The individual VGSC subtypes can generate unique signatures in different cells and multiple expression in single cells (24). Here, we also confirmed that Nav1.5 transcripts predominantly possessed the D1:S3 5' rather than its 3 ' splice form counterparts in ovarian cancer cells, but not in normal cells and tissues. Previous research has also revealed that the D1:S3 3' VGSC is functionally expressed in breast and prostate cancer; therefore, the D1:S3 5 ' splice variants might belong to embryonic genes $(19,21,25,26)$. Western blot analysis results indicated that Nav1.5 had two molecular weights, it was supposed that the normal $220 \mathrm{kDa}$ size molecule might be the functional glycosylated Nav1.5 and the other smaller molecule might be the non-functional misglycosylated truncated protein $(13,24)$. By using immunohistochemistry, the Nav1.5 protein in human ovarian cancer was shown to be located in epithelial cells, but not originating from immune cells (27). Taken together, these data were highly consistent with the findings in vitro and suggested that the overexpression of Nav1.5 might play important roles in the progression of ovarian cancer to the metastatic mode.

At present, the mechanisms of VGSC participating in the modulation of metastatic cascade remain unknown, but several possibilities might be considered, such as protein-protein interactions, intracellular trafficking and gene functional expression levels are involved VGSC in transcriptional, pretranslational, translational, post-translational regulation and some gene expression levels have been reported to enhance prostate cancer metastasis potential by up-regulating VGSC functional expression as signaling intermediates (28). Gillet et al (29) recently proposed that VGSC enhanced the invasion of cancer cells by favoring the PH-dependent activity of cysteine cathepsins in breast cancers. Our previous study revealed that VGSC potentiate the invasion of breast cancer possibly by increasing the expression of MMP-9 mRNA (30).
In conclusion, Nav1.5 functional expression in ovarian cancer might represent a novel mechanism for potentiating cellular metastasis and a promising new therapeutic strategy against ovarian cancers. However, further electrophysiological and pharmacological characterization of these cell lines needs to be undertaken.

\section{Acknowledgements}

We would like to thank Dr J. Diss and Dr S. Roger for giving helpful suggestions on our experiment and Professor S. Lassmann for her helpful commentaries on the manuscript.

\section{References}

1. Ayhan A, Gultekin M, Dursun P, et al: Metastatic lymph node number in epithelial ovarian carcinoma: does it have any clinical significance? Gynecol Oncol 108: 428-432, 2008.

2. Börjesson SI and Elinder F: Structure, function and modification of the voltage sensor in voltage-gated ion channels. Cell Biochem Biophys 52: 149-174, 2008.

3. Fiske JL, Fomin VP, Brown ML, Duncan RL and Sikes RA: Voltage-sensitive ion channels and cancer. Cancer Metastasis Rev 25: 493-500, 2006.

4. Le Guennec JY, Ouadid-Ahidouch H, Soriani O, Besson P, Ahidouch A and Vandier C: Voltage-gated ion channels, new targets in anti-cancer research. Recent Pat Anticancer Drug Discov 2: 189-202, 2007.

5. Isom LL: The role of sodium channels in cell adhesion. Front Biosci 7: 12-23, 2002.

6. Roger S, Potier M, Vandier C, Besson P and Le Guennec JY: Voltage-gated sodium channels: new targets in cancer therapy? Curr Pharm Des 12: 3681-3695, 2006.

7. Catterall WA: From ionic currents to molecular mechanisms: the structure and function of voltage-gated sodium channels. Neuron 26: 13-25, 2000.

8. Palmer CP, Mycielska ME, Burcu H, et al: Single cell adhesion measuring apparatus (SCAMA): application to cancer cell lines of different metastatic potential and voltage-gated $\mathrm{Na}^{+}$channel expression. Eur Biophys J 37: 359-368, 2008.

9. Goldin AL, Barchi RL, Caldwell JH, et al: Nomenclature of voltage-gated sodium channels. Neuron 28: 365-368, 2000.

10. Goldin A: Resurgence of sodium channel research. Annu Rev Physiol 63: 871-894, 2001.

11. Bennett E, Smith B and Harper J: Voltage-gated $\mathrm{Na}^{+}$channels confer invasive properties on human prostate cancer cells. Pflügers Arch 447: 908-914, 2004.

12. Roger S, Besson P and Le Guennec J: Involvement of a novel fast inward sodium current in the invasion capacity of a breast cancer cell line. Biochim Biophys Acta 1616: 107-111, 2003.

13. Roger S, Rollin J, Barascu A, et al: Voltage-gated sodium channels activity is involved in the metastatic process of human non-small cell lung cancer. Int J Biochem Cell Biol 39: 774-786, 2007.

14. Li M, Huang ZJ, Dong WH, et al: Disfigurement of p16INK4A gene expression in development of ovarian cancer and the mechanism. Zhonghua Fu Chan Ke Za Zhi 41: 408-412, 2006.

15. Kenneth KJ and Thomas TD: Analysis of relative gene expression data using real-time quantitative PCR and the 2(-Delta Delta C(T)) method. Methods 25: 402-408, 2001.

16. Vanoye CG, Lossin C, Rhodes TH and George AL Jr: Singlechannel properties of human Nav1.1 and mechanism of channel dysfunction in SCN1A-associated epilepsy. J Gen Physiol 127: 1-14, 2006.

17. Thimmapaya R, Neelands $\mathrm{T}$, Niforatos $\mathrm{W}$, et al: Distribution and functional characterization of human Navl.3 splice variants. Eur J Neurosci 22: 1-9, 2005.

18. Diss J, Stewart S, Fraser S, et al: Expression of skeletal muscletype voltage-gated $\mathrm{Na}^{+}$channel in rat and human prostate cancer cell lines. FEBS Lett 427: 5-10, 1998.

19. Djamgoz M: Voltage-gated sodium channel activity and metastasis: a novel approach to understanding the pathophysiology of prostate cancer. J Physiol 513P: 21-22, 1998. 
20. Nakajima T, Kubota N, Tsutsumi T, et al: Eicosapentaenoic acid inhibits voltage-gated sodium channels and invasiveness in prostate cancer cells. Br J Pharmacol 156: 420-431, 2009.

21. Fraser SP, Diss JK, Chioni AM, et al: Voltage-gated sodium channel expression and potentiation of human breast cancer metastasis. Clin Cancer Res 11: 5381-5389, 2005.

22. Fulgenzi G, Graciotti L, Faronato M, et al: Human neoplastic mesothelial cells express voltage-gated sodium channels involved in cell motility. Int J Biochem Cell Biol 38: 1146-1159, 2006.

23. Venables JP: Aberrant and alternative splicing in cancer. Cancer Res 64: 7647-7654, 2004

24. Diss JK, Fraser SP and Djamgoz MB: Voltage-gated $\mathrm{Na}^{+}$ channels: multiplicity of expression, plasticity, functiona implications and pathophysiological aspects. Eur Biophys J 33: 180-193, 2004.

25. Zimmer T, Bollensdorff C, Haufe V, Birch-Hirschfeld E and Benndorf $\mathrm{K}$ : Mouse heart $\mathrm{Na}^{+}$channels: primary structure and function of two isoforms and alternatively spliced variants. Am J Physiol Heart Circ Physiol 282: H1007-H1017, 2002.
26. Monk M and Holding C: Human embryonic genes re-expressed in cancer cells. Oncogene 20: 8085-8091, 2001.

27. Roselli F, Livrea P and Jirillo E: Voltage-gated sodium channel blockers as immunomodulators. Recent Pat CNS Drug Discov 1: 83-91, 2006.

28. Shao D, Okuse K and Djamgoz MB: Protein-protein interactions involving voltage-gated sodium channels: post-translational regulation, intracellular trafficking and functional expression. Int J Biochem Cell Biol 41: 1471-1481, 2009.

29. Gillet L, Roger S, Besson P, et al: Voltage-gated sodium channel activity promotes cysteine cathepsin-dependent invasiveness and colony growth of human cancer cells. J Biol Chem 284: 8680-8691, 2009

30. Gao R, Wang J, Shen Y, Lei M and Wang Z: Functional expression of voltage-gated sodium channels Nav1.5 in human breast caner cell line MDA-MB-231. J Huazhong Univ Sci Technolog Med Sci 29: 64-67, 2009. 